\title{
Concomitant pulmonary artery and aortic embolectomy
}

\author{
P Schraverus ${ }^{1 *}$, JF Adam ${ }^{2}$ \\ From 23rd World Congress of the World Society of Cardio-Thoracic Surgeons \\ Split, Croatia. 12-15 September 2013
}

We report a case of a young patient presenting concomitant pulmonary artery embolism and an intra-aortic thrombus occluding the left subclavian artery due to a patent foramen ovale. This patient was treated under short circulatory arrest and unilateral cerebral perfusion allowing aortic and pulmonary embolectomy and closure of the small PFO. Follow up was uneventful so this case shows a successful treatment of a massive paradoxical aortic embolism and pulmonary embolism. Complete preoperative imaging is necessary to choose the safest cannulation option.

\section{Authors' details}

${ }^{1}$ Cardio-Vascular Surgery, Grand Hopital De Charleroi, Charleroi, Belgium.

${ }^{2}$ Intensive Care, Clinique Notre-Dame de Grâce, Gosselies, Belgium.

Published: 11 September 2013

doi:10.1186/1749-8090-8-S1-P13

Cite this article as: Schraverus and Adam: Concomitant pulmonary

artery and aortic embolectomy. Journal of Cardiothoracic Surgery 20138

(Suppl 1):P13.

* Correspondence: peter_schraverus@yahoo.fr

${ }^{1}$ Cardio-Vascular Surgery, Grand Hopital De Charleroi, Charleroi, Belgium

Full list of author information is available at the end of the article

Submit your next manuscript to BioMed Central and take full advantage of:

- Convenient online submission

- Thorough peer review

- No space constraints or color figure charges

- Immediate publication on acceptance

- Inclusion in PubMed, CAS, Scopus and Google Scholar

- Research which is freely available for redistribution

Submit your manuscript at www.biomedcentral.com/submit
() Biomed Central
C Biomed Central

(C) 2013 Schraverus and Adam; licensee BioMed Central Ltd. This is an Open Access article distributed under the terms of the Creative Commons Attribution License (http://creativecommons.org/licenses/by/2.0), which permits unrestricted use, distribution, and reproduction in any medium, provided the original work is properly cited. 